\title{
BMJ Open Role of viral and bacterial pathogens in causing pneumonia among Western Australian children: a case-control study protocol
}

\author{
Mejbah Uddin Bhuiyan,, ${ }^{1,2}$ Thomas L Snelling, ${ }^{2,3}$ Rachel West, ${ }^{2}$ Jurissa Lang, ${ }^{4}$ \\ Tasmina Rahman, ${ }^{2,5}$ Meredith L Borland, ${ }^{3}$ Ruth Thornton, ${ }^{2,5}$ Lea-Ann Kirkham, ${ }^{2,5}$ \\ Chisha Sikazwe, ${ }^{4}$ Andrew C Martin, ${ }^{3}$ Peter C Richmond, ${ }^{1,3}$ David W Smith, ${ }^{4}$ \\ Adam Jaffe, ${ }^{6}$ Christopher C Blyth ${ }^{1,2,3,4}$
}

To cite: Bhuiyan MU,

Snelling TL, West R, et al. Role of viral and bacterial pathogens in causing pneumonia among Western Australian children: a case-control study protocol. BMJ Open 2018;8:e020646. doi:10.1136/ bmjopen-2017-020646

- Prepublication history for this paper is available online. To view these files, please visit the journal online (http://dx.doi. org/10.1136/bmjopen-2017020646).

Received 14 November 2017 Revised 27 December 2017 Accepted 12 February 2018

Check for updates

For numbered affiliations see end of article.

Correspondence to

Mejbah Uddin Bhuiyan;

Mejbah.Bhuiyan@uwa.edu.au

\section{ABSTRACT}

Introduction Pneumonia is the leading cause of childhood morbidity and mortality globally. Introduction of the conjugate Haemophilus influenzae B and multivalent pneumococcal vaccines in developed countries including Australia has significantly reduced the overall burden of bacterial pneumonia. With the availability of molecular diagnostics, viruses are frequently detected in children with pneumonia either as primary pathogens or predispose to secondary bacterial infection. Many respiratory pathogens that are known to cause pneumonia are also identified in asymptomatic children, so the true contribution of these pathogens to childhood communityacquired pneumonia (CAP) remains unclear. Since the introduction of pneumococcal vaccines, very few comprehensive studies from developed countries have attempted to determine the bacterial and viral aetiology of pneumonia. We aim to determine the contribution of bacteria and viruses to childhood CAP to inform further development of effective diagnosis, treatment and preventive strategies.

Methods and analysis We are conducting a prospective case-control study (PneumoWA) where cases are children with radiologically confirmed pneumonia admitted to Princess Margaret Hospital for Children (PMH) and controls are healthy children identified from PMH outpatient clinics and from local community immunisation clinics. The case-control ratio is $1: 1$ with 250 children to be recruited in each arm. Nasopharyngeal swabs are collected from both cases and controls to detect the presence of viruses and bacteria by PCR; pathogen load will be assessed by quantitative PCR. The prevalence of pathogens detected in cases and controls will be compared, the $\mathrm{OR}$ of detection and population attributable fraction to CAP for each pathogen will be determined; relationships between pathogen load and disease status and severity will be explored.

Ethics and dissemination This study has been approved by the human research ethics committees of PMH, Perth, Australia (PMH HREC REF 2014117EP). Findings will be disseminated at research conferences and in peerreviewed journals.

\section{Strengths and limitations of this study}

- This is the first case-control study in Australia to determine the aetiology and relative contribution of respiratory viruses and bacteria to childhood pneumonia during the postpneumococcal vaccination era.

- The study design will estimate how much each respiratory pathogen attributes to childhood pneumonia at a population level after adjusting for demographic factors, pre-existing chronic medical conditions and the presence of other respiratory pathogens.

- Prospective recruitment of frequency matched cases and controls in each age group will adjust the effect of age and pathogen seasonality in causing pneumonia in children.

- Cases are defined as children with radiologically confirmed pneumonia which reduces the interobserver variability and increase the generalisability of the study data.

- Specimens to detect respiratory viruses and bacteria will be collected from the upper respiratory tract (nasopharynx) instead of the actual site of infection, that is, lower respiratory tract. Pathogens detected in nasopharyngeal swab do not necessarily confirm the presence of the same pathogens in the lower respiratory tract; however, evidence of these pathogens in nasopharynx has been found to be associated with lower respiratory tract infection in children in previous epidemiological studies.

\section{INTRODUCTION}

Pneumonia is the leading cause of morbidity and mortality among young children globally. Recent estimates suggest that approximately 120 million new cases of community-acquired pneumonia (CAP) occur each year with nearly 1 million deaths among children aged $<5$ years; most deaths occur in low-resource settings. ${ }^{12}$ The burden of childhood CAP in 
developed countries is lower (approximately 50 cases per 1000 child-years), however, CAP remains an important public health concern with increasing antibacterial resistance, evidence of replacement disease with non-vaccine strains and emergence of new respiratory pathogens. ${ }^{3-5}$ In Australia, CAP is an important cause of hospitalisation of children with 2-8 hospitalisations per 1000 child-years for children $<5$ years old. ${ }^{6}$ In Western Australia, the incidence is especially high for Aboriginal children who have been observed to be at 14 times higher risk of hospitalisation for CAP than non-Aboriginal children. ${ }^{8}$

\section{Aetiology of pneumonia}

Identification of causative micro-organisms in childhood CAP remains an ongoing challenge, affected by both the type of clinical specimens obtained and the testing method used. Previous studies have used a variety of specimens to identify the causative pathogen for childhood pneumonia, including bronchoalveolar lung fluid, blood, nasopharyngeal aspirates, nasopharyngeal swabs and pleural fluid (for complicated cases). ${ }^{35}$ A variety of respiratory viruses and bacteria are associated with childhood CAP in developed countries ${ }^{9-21}$ (table 1). Other pathogens such as fungi including endemic mycoses are less common causes of $\mathrm{CAP}^{22}$

\section{Bacteria}

Historically, bacteria were considered to be the most important cause of CAP in children globally. Prior to the introduction of pneumococcal conjugate vaccines (PCV) in developed countries in the early 2000s, Streptococcus pneumoniae (the pneumococcus) was the leading bacterial pathogen causing CAP, identified in 8\%-36\% of young children with $\mathrm{CAP}^{23}$ Other bacteria associated with childhood pneumonia include both encapsulated and non-typeable Haemophilus influenzae, Streptococcus pyogenes, Staphylococcus aureus and Moraxella catarrhalis. ${ }^{22}$ Gram-negative enteric bacteria and atypical intracellular bacteria, for example, Mycoplasma pneumoniae and Chlamydophila pneumoniae have also been reported to cause childhood CAP. ${ }^{22}{ }^{24}$ M. pneumoniae appears to be detected more commonly among school aged than in younger children. ${ }^{25} 26$ The burden of bacterial pneumonia has reduced significantly in Europe, the USA and Australia since the introduction of both the conjugate $H$. influenzae $\mathrm{B}$ and multivalent PCV into the routine immunisation schedule. ${ }^{727-30}$ However, bacteria still remain as important causes of pneumonia in many developing settings where the vaccines have not been introduced or recently introduced. ${ }^{31} 32$

\section{Viruses}

With the development of, and more frequent use of molecular diagnostics, respiratory viruses are increasingly detected among children with pneumonia, particularly children $<5$ years old. ${ }^{3}$ Among the viruses, respiratory syncytial virus (RSV), influenza virus, human parainfluenza virus (HPIV), human rhinovirus (HRV) and human adenovirus (HAdV) are commonly detected in children with pneumonia. The new sensitive molecular techniques have enabled detection of new respiratory viruses including human metapneumovirus (HMPV), novel human coronavirus $(\mathrm{HCoV})$, human bocavirus and emerging strains of influenza virus in childhood CAP. ${ }^{33}$ In developed countries, up to $81 \%$ of young children with CAP have viruses detected in respiratory specimens, with RSV the most frequently detected virus in most studies, ranging from $7 \%$ to $48 \%$. $^{341013151734}$

\section{Viral-bacterial coinfection}

There is evidence that respiratory viruses may have a role in facilitating bacterial colonisation, enhancing bacterial infection and/or in enhancing disease severity either directly or indirectly. Viruses disrupt the respiratory epithelium barrier and also alter the defence mechanism of host epithelium potentially leading to bacterial entrance and enabling secondary bacterial infection. ${ }^{35}{ }^{36}$ The incidence of invasive pneumococcal infection has been observed to be higher during increased seasonal activity of some respiratory viruses including influenza, RSV, parainfluenza 3 and adenovirus. ${ }^{37} 38$ Further, in clinical trials in South Africa, conjugate pneumococcal vaccination resulted in overall decrease in virus-associated pneumonia, suggesting interactions between respiratory viruses and pneumococcus in causing pneumonia in children. ${ }^{39}$ In Australia, ecological data have demonstrated a reduction in viral pneumonia following introduction of PCV vaccines. ${ }^{40}$ RSV has been reported to facilitate bacterial colonisation with $H$. influenzae, Streptococcus pyogenes, Staphylococcus aureus, and M. catarrhalis in the nasopharynx of young children with acute respiratory infection. ${ }^{41}$ Another study in Australia identified Streptococcus pneumoniae, H. influenzae and Staphylococcus aureus in 25\% patients in intensive care who were admitted with severe influenza A infection during 2009 influenza pandemic. ${ }^{42}$ The patients with viral-bacterial coinfection has been reported to suffer for treatment failure, longer ventilator support and increased likelihood of intensive care unit admission. ${ }^{12}{ }^{43-45}$

\section{Relationship between bacterial-viral load and severity of pneumonia}

The relationship between nasopharyngeal pathogen load and the disease severity had been previously assessed in data from several pneumonia epidemiological studies. These studies have demonstrated that nasopharyngeal pathogen load could predict the severity of pneumonia in children. A study in the USA among infants reported that a higher RSV load was associated with longer hospitalisation, respiratory failure and admission to intensive care unit. ${ }^{46}$ In Vietnam, children with radiological confirmed pneumonia had higher pneumococcal load compared with children with other respiratory illness and the load of pneumococcus was a 15-fold higher in children with viral coinfection compared with no viral coinfection. ${ }^{47}$ Other studies in Kenya and the Netherlands reported the higher nasopharyngeal RSV loads in children with severe respiratory infections compared with less severe infections. $^{48} 49$ 
Table 1 Respiratory bacteria and viruses associated with childhood pneumonia in developed countries

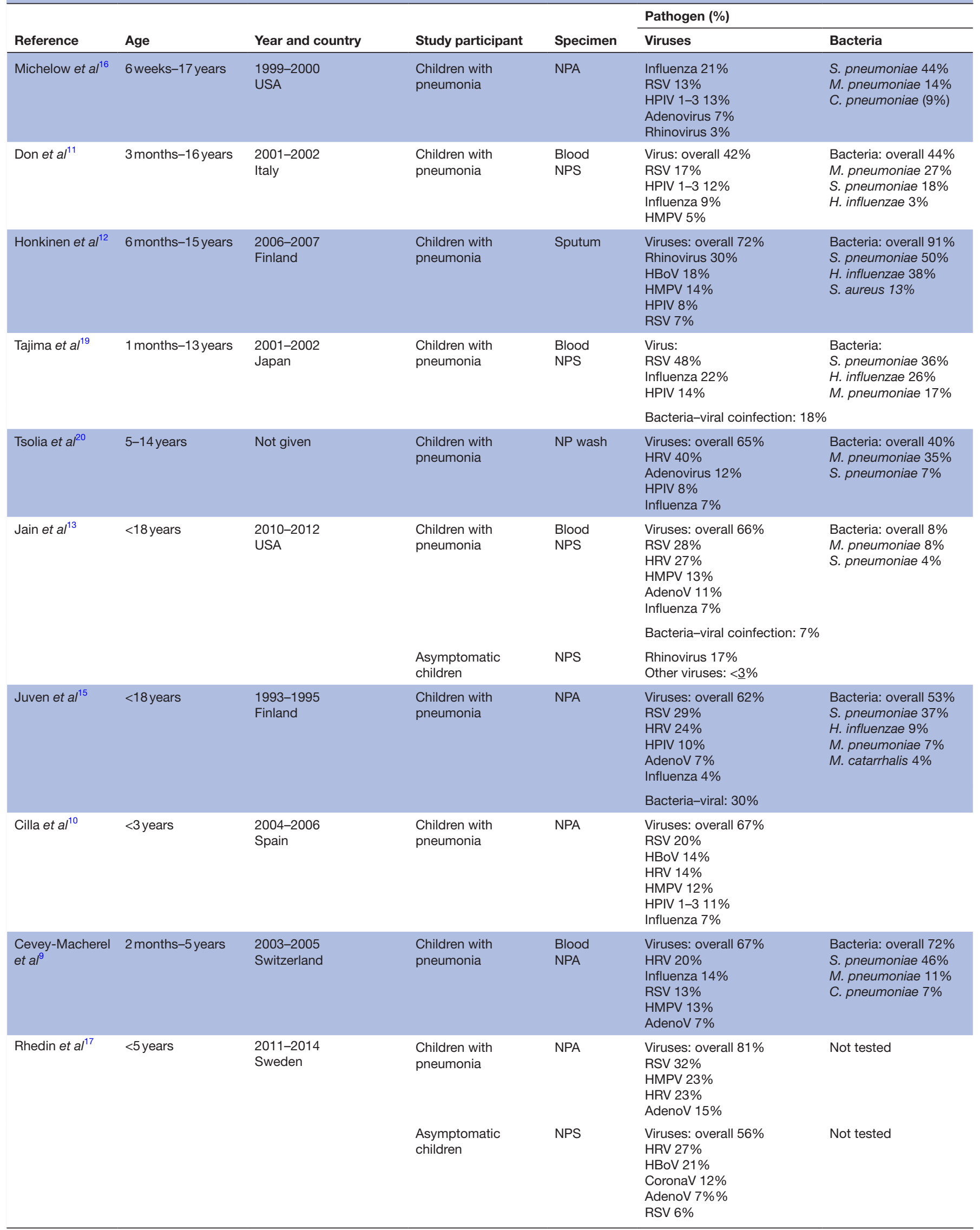

Continued 
Table 1 Continued

\begin{tabular}{|c|c|c|c|c|c|c|}
\hline \multirow[b]{2}{*}{ Reference } & \multirow[b]{2}{*}{ Age } & \multirow[b]{2}{*}{ Year and country } & \multirow[b]{2}{*}{ Study participant } & \multirow[b]{2}{*}{ Specimen } & \multicolumn{2}{|l|}{ Pathogen (\%) } \\
\hline & & & & & Viruses & Bacteria \\
\hline Spuesens et $a l^{18}$ & 3 months -16 years & $\begin{array}{l}\text { 2008-2011 } \\
\text { The Netherlands }\end{array}$ & $\begin{array}{l}\text { Children with } \\
\text { respiratory infections }\end{array}$ & $\begin{array}{l}\text { Blood } \\
\text { NPS }\end{array}$ & Not tested & $\begin{array}{l}\text { Bacteria: } \\
\text { S. pneumoniae } 28 \% \\
\text { M. catarrhalis } 23 \% \\
\text { M. pneumoniae } 16 \% \\
\text { H. influenzae } 16 \% \\
\text { S. aureus } 10 \%\end{array}$ \\
\hline Jansen et $a l^{14}$ & $<6$ years & $\begin{array}{l}\text { 2007-2009 } \\
\text { The Netherlands }\end{array}$ & $\begin{array}{l}\text { Children with } \\
\text { respiratory infections }\end{array}$ & NW & $\begin{array}{l}\text { Viruses: overall } 72 \% \\
\text { RSV } 26 \% \\
\text { HRV 20\% } \\
\text { AdenoV 9\% } \\
\text { Influenza 6\% } \\
\text { HMPV 6\% }\end{array}$ & Not tested \\
\hline \multirow[t]{2}{*}{ Singleton et $a l^{21}$} & $<3$ years & $\begin{array}{l}2005-2007 \\
\text { USA }\end{array}$ & $\begin{array}{l}\text { Children with } \\
\text { respiratory infections }\end{array}$ & $\begin{array}{l}\text { Blood } \\
\text { NPS }\end{array}$ & $\begin{array}{l}\text { Viruses: overall } 90 \% \\
\text { HRV } 44 \% \\
\text { AdenoV } 30 \% \\
\text { RSV } 23 \% \\
\text { HPIV } 18 \% \\
\text { HMPV } 15 \%\end{array}$ & $\begin{array}{l}\text { Bacteria: overall } 3 \% \\
\text { S. pneumoniae } 2 \%\end{array}$ \\
\hline & & & $\begin{array}{l}\text { Asymptomatic } \\
\text { children }\end{array}$ & NPS & $\begin{array}{l}\text { Virus: overall 52\% } \\
\text { HRV 33\% } \\
\text { AdenoV } 16 \% \\
\text { HMPV } 7 \% \\
\text { RSV } 4 \% \\
\text { HPIV } 3 \%\end{array}$ & Not tested \\
\hline
\end{tabular}

AdenoV, human adenovirus; CoronaV, corona virus; C. pneumoniae, Chlamydophila pneumoniae; H. influenzae, Haemophilus influenzae; HBoV, human bocavirus; HPIV, human parainfluenza virus; HMPV, human metapneumovirus; HRV, human rhinovirus; NPA, nasopharyngeal aspirate; NP$\underline{S}$, nasopharyngeal swab; NW, nasal wash; M. catarrhalis, Moraxella catarrhalis; M. pneumoniae, Mycoplasma pneumoniae; RSV, respiratory syncytial virus; S. aureus, Staphylococcus aureus; S. pneumoniae, Streptococcus pneumoniae.

\section{Presence of respiratory pathogens among asymptomatic children}

Despite a number of studies in developed countries designed to explore the aetiology of acute respiratory infections in children, including CAP, few included healthy/asymptomatic children as controls. ${ }^{13} 14171821$ These studies including healthy controls have identified the asymptomatic presence of pathogens known to be associated with pneumonia (table 1). Additionally, in other epidemiological studies in similar settings, nasopharyngeal carriage of respiratory bacteria and viruses known to be associated with pneumonia have also been reported in healthy children. ${ }^{50-54}$ Together these findings suggest that asymptomatic carriage may be common in the healthy population, thereby making interpreting of CAP studies more challenging.

\section{Significance of this study}

Although the PCV have successfully reduced the hospitalisation rate with CAP in children in developed countries, pneumococcus remains as an important pathogen because of emergence of non-vaccine serotypes with potential to cause severe and complicated pneumonia, and empyema. ${ }^{7}$ With many cases being associated with respiratory viruses (table 1 ), the current immunisation strategies focussing exclusively on bacterial pneumonia are expected to have modest impacts on further pneumonia case reduction. Apart from the annual influenza vaccines, to date there are no other licensed vaccine for any respiratory viruses that can be used in the community. It is critical to understand the relative contribution of specific bacterial and viral pathogens to childhood CAP, to help inform the development of new therapeutics for pneumonia, including antivirals and to support ongoing efforts for new preventive strategies such as vaccines targeting RSV and parainfluenza which are in advanced stages of development. This question constitutes the primary aim of this study. Additionally, unveiling relationships between pathogen load and pathogenicity will inform tools for more accurate attribution of the infective cause of CAP, allowing better diagnosis and management of pneumonia cases using antibiotic and antiviral therapies. Finally, this study will identify emergent serotypes of 
pneumococcus causing CAP among vaccinated children, informing the design of future pneumococcal vaccines.

The detection of micro-organisms in asymptomatic children makes it more challenging to ascertain the exact contribution of any pathogen to disease with uncontrolled pneumonia aetiological studies. CAP case-control studies in children in developing countries are not generalisable to developed countries like Australia where health infrastructure, including access to vaccination, is much better. ${ }^{21}{ }^{55-57}$ Recently, findings from two published case-control studies on childhood pneumonia in developed countries, one in the USA and the other in Sweden, have both had limitations (table 1; Jain et al and Rhedin et al). ${ }^{1317}$ The Swedish study was relatively underpowered (93 X-ray confirmed cases and 240 controls) to assess attributable risk for a range of viral pathogens and in the US study, healthy controls were not enrolled contemporaneously or from all study sites which might have biased the inference for specific pathogens. The proposed study is the first case-control study of pneumonia aetiology in Australia in post $\mathrm{PCV}$ vaccination era, where 250 radiologically confirmed hospitalised pneumonia cases $(n=250)$ will be compared with 250 age group frequency-matched healthy controls for both the presence of respiratory pathogens and quantitative load of pathogens. The proposed study is expected to address the limitations from previous case-control studies through recruitment of an appropriate number of cases and controls contemporaneously and from the same study sites.

\section{Aim and objectives}

The aim of this study is to determine the contribution of bacterial and viral respiratory pathogens to CAP among West Australian children.

\section{Primary objective}

- To assess the pathogenicity of respiratory viruses and bacteria and pathogen-specific population-attributable risk to radiologically proven CAP in children.

\section{Secondary objectives}

To determine the frequency of respiratory virus-bacterial coinfection in children with CAP compared with healthy children, and to assess the contribution of coinfection to clinical outcome and severity.

To compare nasopharyngeal viral and bacterial loads in children with CAP compared with healthy children, and to assess the importance of pathogen load to disease status and severity.

To identify the nasopharyngeal quantitative threshold for each pathogen which optimally discriminates (sensitivity and specificity) children with CAP from asymptomatic children.

\section{METHODS AND ANALYSIS}

\section{Study design and population}

This is a prospective case-control study (named as PneumoWA study) with a case-control ratio of 1:1. Children
Table 2 Inclusion and exclusion criteria for cases and controls in PneumoWA study, Perth, Western Australia

\begin{tabular}{|c|c|c|}
\hline $\begin{array}{l}\text { Study } \\
\text { group }\end{array}$ & Inclusion/exclusion & Criteria \\
\hline \multirow[t]{2}{*}{ Case } & Inclusion & $\begin{array}{l}\text { Children }<18 \text { years old presenting to } \\
\text { hospital within the past }<36 \text { hours } \\
\text { X-ray confirmed pneumonia } \\
\text { Presumed infective aetiology } \\
\text { A full blood count performed } \\
\text { One nasopharyngeal swab obtained } \\
\text { within } 36 \text { hours of hospital presentation }\end{array}$ \\
\hline & Exclusion & $\begin{array}{l}\text { Previously hospitalised within } 14 \text { days } \\
\text { of current presentation } \\
\text { Previously enrolled as a case or } \\
\text { control in PneumoWA study }\end{array}$ \\
\hline \multirow[t]{2}{*}{ Control } & Inclusion & $\begin{array}{l}\text { Children }<18 \text { years old } \\
\text { One nasopharyngeal swab obtained } \\
\text { during enrolment }\end{array}$ \\
\hline & Exclusion & $\begin{array}{l}\text { Children attending hospital or clinic } \\
\text { for treatment or follow-up of a } \\
\text { lower or upper respiratory illness } \\
\text { (including all respiratory or ENT clinic } \\
\text { attendees), or proven or probable } \\
\text { vaccine preventable disease (including } \\
\text { meningitis, pertussis, measles and } \\
\text { varicella) } \\
\text { Children attending non-routine/high- } \\
\text { risk immunisation service (including } \\
\text { vaccine counselling or adverse event } \\
\text { follow-up) } \\
\text { Hospitalised within } 14 \text { days of } \\
\text { presentation } \\
\text { Previously enrolled as a case or } \\
\text { control in PneumoWA study }\end{array}$ \\
\hline
\end{tabular}

ENT, ear, nose and throat.

attending publicly funded health services in metropolitan Perth, Western Australia are being recruited. Enrolment of children into the study commenced at Princess Margaret Hospital for Children (PMH), Perth, Western Australia in May 2015.

Both cases and controls are enrolled following the inclusion and exclusion criteria of the study (table 2). Cases are defined as children attending PMH with CAP identified by their treating clinician. The operational definition of pneumonia for this study was: (a) the presence of one or more of following clinical symptoms: cough, fever or increased work of breathing, (b) alveolar consolidation as judged by the treating clinician and paediatric radiologist and (c) presumed infective aetiology that requiring antibiotic therapy. Control group consists of contemporaneously healthy children attending PMH outpatient clinics or a local community immunisation clinic with no signs of respiratory illness.

\section{Sample size calculation for the primary objective}

A total of 250 cases and 250 controls will be enrolled. The power of the study to detect a significantly higher rate of pathogen detection among cases versus controls is dependent on the frequency of pathogen detection in healthy controls. Using data from previously published literature among pneumonia cases and healthy controls, ${ }^{12}{ }^{51}$ it was estimated that a sample size of 250 pneumonia cases and 250 healthy controls would provide $80 \%$ power to identify a significant excess in pathogen detection (lower bound of 
$95 \%$ CI $>1$ ) among cases compared with controls, ranging from at least $3 \%$ (for influenza) to $15 \%$ (for rhinovirus).

\section{Identification and enrolment of study participants \\ Cases}

Cases are identified daily by monitoring presentations to the emergency department (ED) and admission records at PMH. After assessment against inclusion and exclusion criteria, parent(s) are approached by a trained research assistant to consent for enrolment followed by data and biological specimen collection.

\section{Controls}

Controls are enrolled prospectively and contemporaneously by trained research staff during attendance at PMH outpatient clinics or at the Rheola street immunisation clinic, Perth, Western Australia. Parents are approached while awaiting for their child's medical appointment or routine immunisation. Controls are frequency matched to cases in each age groups ( $<1$ year, $1-4$ years, $5-9$ years and $\geq 10$ years) by prospectively setting targets for control enrolment based on the number of cases enrolled in each age group in the preceding 2 weeks.

\section{Data collection}

Following consent, epidemiological data relating to pertinent demographic factors such as age, sex, indigenous status, the presence of a smoker in the household, premature birth and pre-existing chronic health conditions such as immunodeficiency, neurological disorder and chronic cardiac disease are collected on all study participants (table 3) using a standardised paper-based data collection form by interviewing the parents. Data on clinical management and disease outcome of the cases are obtained by reviewing the hospital medical records. Patient's medical record file will be revisited to obtain any missing medical information for that illness episode. Immunisation record for each child is collected from Australian Immunisation Record (AIR). Each participant is allocated a unique identification number to allow anonymisation. The data are entered onto a secure web-based research database (Medrio).

\section{Specimen collection}

Nasopharyngeal swabs (NPS) are collected from all case and controls using a FLOQswab (Copan Diagnostics, Murrieta, California, USA) by trained research staff following WHO recommended procedures. ${ }^{58}$ After collection, the swab is stored in $1 \mathrm{~mL}$ skim milktryptone-glucose-glycerol broth which is suitable for storage and transportation of respiratory bacteria and viruses. $^{5960}$ Other specimens recommended but not mandated include blood cultures and EDTA blood for pneumococcal PCR. In the setting of pleural effusion, culture and pneumococcal PCR is also recommended. Despite the sensitivity and specificity of lung aspirate, this is not being undertaken in PneumoWA given the invasive nature and risk of the procedure. ${ }^{61}$
Processing, storage and transportation of specimen

After collection, the NPS specimen is kept on ice and processed within 4 hour at the research laboratory of the PMH Children's Clinical Research Facility. The NPS specimen is vortexed for $30 \mathrm{~s}$ before divided into two aliquots with $500 \mu \mathrm{L}$ each for bacterial and viral assessment, and the vials stored at $-80^{\circ} \mathrm{C}$. Specimens are batched and periodically sent to reference laboratories for PCR testing. The NPS specimens are transported to the reference laboratories on ice on the same day of testing to avoid an additional freeze-thaw cycle.

\section{Laboratory analysis}

NPS are tested for viral presence and load at PathWest Laboratory Medicine WA, Perth, Australia and for bacterial load at research laboratories at the School of Biomedical Science, University of Western Australia, Perth, Western Australia.

The respiratory viruses and atypical bacterial pathogens such as $M$. pneumoniae and C. pneumoniae are detected by multiplex real-time PCR at PathWest Laboratories (QEII) using previously described primers and probes. ${ }^{62}{ }^{63}$ In detail, nucleic acid is extracted from the NPS using the MagNA Pure 96 System (Roche Applied Science, Indianapolis, Indiana, USA). Extracted nucleic acids are tested in Applied Biosystems ViiA7 Real-time PCR system (ThermoFisher Scientific, Massachusetts, USA) for common respiratory virus panel including Influenza $\mathrm{A} / \mathrm{H} 1 \mathrm{~N} 1$ and $\mathrm{A} / \mathrm{H} 3 \mathrm{~N} 2$, Influenza $\mathrm{B}$, HPIV type 1-3, HMPV and RSV types A and B. Targets for HAdv and HCoV OC43, HCoV 229E, HCoV HKU1 and HCoV NL63, HRV and atypical bacteria are set up in Qiagen Rotor-Gene TaqMan Analysers for Real-Time PCR. PCR assays directed at the 5' non-translated region of HRV species A-C are used to distinguish rhinoviruses from enterovirus species A-D were adapted from Osterback $e t a l^{64}$ (Merritt $e t a l$,). Quantitative viral load is assessed on all NPS specimens that are positive for respiratory viruses. The primers, probes and protocols for determining the viral load for a range of viral pathogens in NPS specimens have been developed by PathWest (Sikazwe et al, unpublished data). A nucleic acid standard is developed using purified plasmid DNA or in vitro transcribed RNA, and the concentration of the DNA and/or RNA standard is quantified using fluorescent dyes. Following this, a standard curve is generated from serial 10-fold dilutions of the DNA and/or RNA standards mentioned above. The viral load in the NPS specimen is quantified by interpolating from the appropriate standard curve. The viral load is reported in viral copies/mL.

Quantification of bacterial loads in NPS specimen is performed using quantitative real-time PCR (qPCR) using methods established at UWA School of Biomedical Science (Kirkham et al unpublished data). NPS in STGG are centrifuged at high speed to pellet bacteria and associated cells, DNA is then extracted from the pellet using enzymatic extraction and the QIAamp DNA 
Table 3 Demographic and medical information collected from study participants in PneumoWA study, Perth, Western Australia

\begin{tabular}{|c|c|c|}
\hline \multirow[b]{2}{*}{ Data parameter } & \multicolumn{2}{|c|}{ Study group } \\
\hline & Cases & Controls \\
\hline Date of birth & $x$ & $x$ \\
\hline Gender & $X$ & $x$ \\
\hline Indigenous status & $X$ & $x$ \\
\hline $\begin{array}{l}\text { Risk factors for pneumonia } \\
\text { a. Household smoking contact } \\
\text { b. Prematurity } \\
\text { c. Immunodeficiency/immunosuppression } \\
\text { d. Congenital or chromosomal abnormality } \\
\text { e. Cochlear implants } \\
\text { f. Intracranial shunt } \\
\text { g. Chronic respiratory and cardiac illness } \\
\text { h. Childcare attendance } \\
\text { i. Previous invasive bacterial infection }\end{array}$ & $X$ & $x$ \\
\hline
\end{tabular}

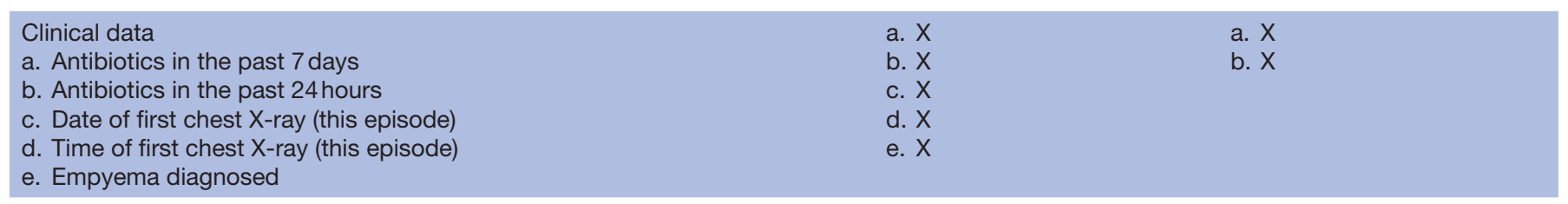

Additional clinical data

$X$

a. Symptom onset date

b. Symptoms present during illness

c. Weight $(\mathrm{kg})$

d. Symptoms (yes/no):

i. Cough

ii. Runny nose

iii. Difficulty/rapid breathing

iv. Vomiting

v. Diarrhoea

vi. Rash

vii. Reduced oral intake

viii. Other symptoms

e. Respiratory rate on presentation

f. Auscultatory finding (yes/no/unknown)

i. Wheeze

ii. Crackles/crepitations

g. Highest temperature recorded

h. Hospital admission (yes/no)

i. ICU admission (yes/no)

j. $\mathrm{SpO}_{2}$ on admission and rate of $\mathrm{O}_{2}$ delivery

k. Supplemental $\mathrm{O}_{2}$ required (yes $/ \mathrm{no}$ )

I. Intravenous fluids or supplemental feeds (yes/no)

m. Positive pressure ventilation (yes/no)

n. Length of stay (days)

o. Discharge status (home/transfer/died)

\begin{tabular}{|c|c|}
\hline $\begin{array}{l}\text { Blood results } \\
\text { a. White cell count (first available) } \\
\text { b. Neutrophil count (first available) } \\
\text { c. CRP (first available) } \\
\text { d. Blood culture and PCR results }\end{array}$ & $\mathrm{x}$ \\
\hline Nasopharyngeal aspirate (if done) results & $x$ \\
\hline $\begin{array}{l}\text { Pleural fluid results (if done): } \\
\text { Culture and PCR result }\end{array}$ & $\mathrm{X}$ \\
\hline
\end{tabular}

$\mathrm{CRP}, \mathrm{C}$ reactive protein; $\mathrm{ICU}$, intensive care unit; $\mathrm{SpO}_{2}$, oxygen saturation.

minikit (Qiagen, Chadstone, VIC, Australia) as previously described. ${ }^{65}$ Real-time qPCR to detect $S$. pneumoniae, $S$. aureus, $M$. catarrhalis and non-typeable $H$. influenzae is conducted on the CFX96 real-time PCR detection system (Bio-Rad, California, USA) using the primers and probes listed in table 4. A standard curve is generated for each run for each reference strain. All samples are run in duplicate and density is calculated as an average of the two measurements. The bacterial load is assessed in colony forming units $(\mathrm{CFU}) / \mathrm{mL}$ which is equivalent to 


\begin{tabular}{|c|c|c|}
\hline Detected species & Primer/probe & Sequence $\left(5^{\prime}\right.$ to $\left.3^{\prime}\right)$ \\
\hline \multirow{3}{*}{ H. influenzae } & fucP fwd & GCCGCTTCTGAGGCTGG \\
\hline & fucP rev & AACGACATTACCAATCCGATGG \\
\hline & fucP probe & 6FAM-TCCATTACTGTITGAAATAC-MGBNFQ \\
\hline \multirow[t]{3}{*}{ H. influenzae } & hpd3 fwd & GGTTAAATATGCCGATGGTGTTG \\
\hline & hpd3 rev & TGCATCTITACGCACGGTGTA \\
\hline & hpd3 probe & HEX-TTGTGTACACTCCGT/ZEN/TGGTAAAAGAACTTGCAC-3C6 \\
\hline \multirow[t]{3}{*}{ S. pneumoniae } & lytA fwd & ACGCAATCTAGCAGATGAAGCA \\
\hline & lytA rev & TCGTGCGTITTAATTCCAGCT \\
\hline & lytA probe & 6FAM-TGCCGAAAACGCTTGATACAG-GGAG-BHQ1 \\
\hline \multirow[t]{3}{*}{ M. catarrhalis } & copB fwd & CGTGTTGACCGTTTTGACTTT \\
\hline & copB rev & CATAGATTAGGTTACCGCTGACG \\
\hline & copB probe & HEX-ACCGACATCAACCCAAGCTTTGG-BHQ1 \\
\hline \multirow[t]{3}{*}{ S. aureus } & nuc fwd & CATCCTAAAAAAGGTGTAGAGA \\
\hline & nuc rev & 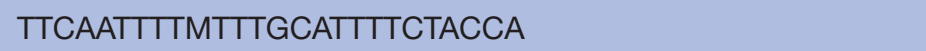 \\
\hline & nuc probe & HEX-TTTTCGTAAATGCACTTGCTTCAGGACCA-BHQ1 \\
\hline
\end{tabular}

H. influenzae, Haemophilus influenza; M. catarrhalis, Moraxella catarrhalis; S. aureus, Staphylococcus aureus; S. pneumoniae, Streptococcus pneumoniae.

copies/mL assuming one copy of a bacteria would yield one colony forming unit.

\section{Data analysis plan}

The frequency and proportion positive for each respiratory pathogen among both cases and controls will be assessed. Where numbers permit, virus subtypes will be reported separately. These proportions will be compared across the two groups to identify if there are any specific pathogens that are detected more frequently among cases than among controls. We will report the crude OR of detection for each respiratory pathogen among CAP cases versus controls. We will also report the adjusted OR for each pathogen after adjustment for demographic factors (eg, age, sex, the presence of a smoker in the household and premature birth), and the presence of other pathogens using multivariable logistic regression (referred to as model 1). The adjusted OR of detection among cases versus controls will be taken to be indicative of the pathogenicity of each organism; the higher the OR the higher the indicative pathogenicity of that microorganism. Using the proportion of cases infected and the adjusted OR for each pathogen, the population level attributable fraction of CAP will be calculated using the method of Greenland and Drescher. ${ }^{66}$ The frequency and proportion of cases and controls having more than one respiratory virus or bacteria detected will be reported. Where numbers permit, a multivariable regression model will be developed to explore the existence of significant pair-wise interactions between respiratory pathogens and disease status. Disease severity for the cases will be assessed using Respiratory Index of Severity in Children score based on Australian children growth standard. ${ }^{67-69}$ Where numbers permit, we will explore the relationship between detection of specific pathogens and severe disease (vs control status) using multivariable logistic regression models as described for model 1 (model 2).

We will report the median log-transformed pathogen load of each pathogen for cases and controls and compare them using student t-test or Mann-Whitney U test method, whichever is applicable, to determine if the pathogen load is different between cases and controls. A multivariable regression analysis (model 3) will be performed to determine the odds of being a case for $1 \log _{10}$ increase in pathogen load $/ \mathrm{mL}$ for each viral and bacterial pathogen after adjusting for demographic factors; where numbers permit, the same approach will be used to determine increase in the odds of severe pneumonia (vs control status) (model 4). We will explore receiver-operating curve and corresponding area under the curve to find the optimal load cut-points (sensitivity and specificity) to discriminate CAP cases from controls, and severe CAP from non-severe CAP, for each pathogen. ${ }^{14}$ We will also analyse data using classification and regression tree and Bayesian network methods as alternative approaches, to select thresholds levels for each pathogen load to discriminate between cases and controls. All analyses will be performed using STATA software V.13.0.

\section{Ethics and dissemination}

Ethics

Written informed consent is obtained from parents and assent from children $>7$ years prior to administration of questionnaire and biological specimen collection. The risks and benefits related with participating in the study are clearly informed to parents and children before obtaining the consent. Unique identification number is provided to each participant to ensure anonymity and 
any information collected about a study participant will remain confidential. There is no payment or compensation associated with the participation.

\section{Dissemination}

Findings will be disseminated at national and international conferences and health symposiums. Manuscripts detailing the results of this study will be submitted for publication in peer-reviewed journals. Findings from the study would describe the attributable risk of specific viral and bacterial pathogens in causing childhood pneumonia at population level which might help more efficient diagnosis and management of lower respiratory tract infections (LRTI) including pneumonia in children and could reduce inappropriate of antibiotics to treat LRTI.

\section{Author affiliations}

${ }^{1}$ Division of Paediatrics, Faculty of Health and Medical Sciences, School of Medicine, The University of Western Australia, Perth, Western Australia, Australia

${ }^{2}$ Wesfarmers Centre of Vaccines and Infectious Diseases, Telethon Kids Institute,

Perth, Australia

${ }^{3}$ Department of Infectious Diseases, Princess Margaret Hospital for Children, Perth, Australia

${ }^{4}$ PathWest Laboratory Medicine WA, Perth, Australia

${ }^{5}$ Faculty of Health and Medical Sciences, School of Biomedical Science, The University of Western Australia, Perth, Australia

${ }^{6}$ Faculty of Medicine, School of Women's and Children's Health, University of New South Wales, Sydney, Australia

Contributors CCB conceived the study and TLS, PCR, AJ, RT, L-AK and DWS contributed to its development. MUB and RW have been implementing study activities and MLB and ACM have assisted with recruitment. Laboratory testing have been undertaken by TR, JL and CS. MUB drafted the manuscript. All authors have reviewed the manuscript.

Funding Funding for the study has been provided by the Telethon Perth Children's Hospital Research Fund, Perth Children's Hospital Foundation and Telethon Kids Institute.

\section{Competing interests None declared.}

Patient consent Not required.

Provenance and peer review Not commissioned; externally peer reviewed.

Open Access This is an Open Access article distributed in accordance with the Creative Commons Attribution Non Commercial (CC BY-NC 4.0) license, which permits others to distribute, remix, adapt, build upon this work non-commercially, and license their derivative works on different terms, provided the original work is properly cited and the use is non-commercial. See: http://creativecommons.org/ licenses/by-nc/4.0/

(c) Article author(s) (or their employer(s) unless otherwise stated in the text of the article) 2018. All rights reserved. No commercial use is permitted unless otherwise expressly granted.

\section{REFERENCES}

1. Walker CL, Rudan I, Liu L, et al. Global burden of childhood pneumonia and diarrhoea. Lancet 2013;381:1405-16.

2. Liu L, Oza S, Hogan D, et al. Global, regional, and national causes of under-5 mortality in 2000-15: an updated systematic analysis with implications for the Sustainable Development Goals. Lancet 2016;388:3027-35.

3. Manikam L, Lakhanpaul M. Epidemiology of community acquired pneumonia. Paediatr Child Health 2012;22:299-306.

4. Prayle A, Atkinson M, Smyth A. Pneumonia in the developed world. Paediatr Respir Rev 2011;12:60-9.

5. Rudan I, Boschi-Pinto C, Biloglav Z, et al. Epidemiology and etiology of childhood pneumonia. Bull World Health Organ 2008;86:408-16.

6. Burgner D, Richmond P. The burden of pneumonia in children: an Australian perspective. Paediatr Respir Rev 2005;6:94-100.
7. Strachan RE, Snelling TL, Jaffé A. Increased paediatric hospitalizations for empyema in Australia after introduction of the 7 -valent pneumococcal conjugate vaccine. Bull World Health Organ 2013;91:167-73.

8. Moore H, Burgner D, Carville K, et al. Diverging trends for lower respiratory infections in non-Aboriginal and Aboriginal children. $J$ Paediatr Child Health 2007;43:451-7.

9. Cevey-Macherel M, Galetto-Lacour A, Gervaix A, et al. Etiology of community-acquired pneumonia in hospitalized children based on WHO clinical guidelines. Eur J Pediatr 2009;168:1429-36.

10. Cilla G, Oñate E, Perez-Yarza EG, et al. Viruses in communityacquired pneumonia in children aged less than 3 years old: High rate of viral coinfection. J Med Virol 2008;80:1843-9.

11. Don M, Fasoli L, Paldanius M, et al. Aetiology of community-acquired pneumonia: serological results of a paediatric survey. Scand $J$ Infect Dis 2005;37:806-12.

12. Honkinen $M$, Lahti $E$, Österback R, et al. Viruses and bacteria in sputum samples of children with community-acquired pneumonia. Clin Microbiol Infect 2012;18:300-7.

13. Jain S, Williams DJ, Arnold SR, et al. Community-acquired pneumonia requiring hospitalization among U.S. children. $N$ Engl $J$ Med 2015;372:835-45.

14. Jansen RR, Wieringa J, Koekkoek SM, et al. Frequent detection of respiratory viruses without symptoms: toward defining clinically relevant cutoff values. J Clin Microbiol 2011;49:2631-6.

15. Juvén T, Mertsola J, Waris M, et al. Etiology of community-acquired pneumonia in 254 hospitalized children. Pediatr Infect Dis $J$ 2000;19:293-8.

16. Michelow IC, Olsen K, Lozano J, et al. Epidemiology and clinical characteristics of community-acquired pneumonia in hospitalized children. Pediatrics 2004;113:701-7.

17. Rhedin S, Lindstrand A, Hjelmgren A, et al. Respiratory viruses associated with community-acquired pneumonia in children: matched case-control study. Thorax 2015;70:847-53.

18. Spuesens EB, Fraaij PL, Visser EG, et al. Carriage of Mycoplasma pneumoniae in the upper respiratory tract of symptomatic and asymptomatic children: an observational study. PLOS Med 2013;10:e1001444.

19. Tajima T, Nakayama E, Kondo Y, et al. Etiology and clinical study of community-acquired pneumonia in 157 hospitalized children. $J$ Infect Chemother 2006;12:372-9.

20. Tsolia MN, Psarras S, Bossios A, et al. Etiology of communityacquired pneumonia in hospitalized school-age children: evidence for high prevalence of viral infections. Clin Infect Dis 2004;39:681-6.

21. Singleton RJ, Bulkow LR, Miernyk K, et al. Viral respiratory infections in hospitalized and community control children in Alaska. J Med Virol 2010;82:1282-90.

22. Mclntosh $\mathrm{K}$. Community-acquired pneumonia in children. $N$ Engl $J$ Med 2002;346:429-37.

23. O'Brien KL, Wolfson LJ, Watt JP, et al. Burden of disease caused by Streptococcus pneumoniae in children younger than 5 years: global estimates. Lancet 2009;374:893-902.

24. Grayston JT, Aldous MB, Easton A, et al. Evidence that Chlamydia pneumoniae causes pneumonia and bronchitis. J Infect Dis 1993;168:1231-5.

25. Foy HM. Infections caused by Mycoplasma pneumoniae and possible carrier state in different populations of patients. Clin Infect Dis 1993;17 Suppl 1(Suppl 1):S37-S46.

26. Korppi M, Heiskanen-Kosma T, Kleemola M. Incidence of community-acquired pneumonia in children caused by Mycoplasma pneumoniae: serological results of a prospective, population-based study in primary health care. Respirology 2004;9:109-14.

27. Griffin MR, Zhu Y, Moore MR, et al. U.S. hospitalizations for pneumonia after a decade of pneumococcal vaccination. $N$ Engl $J$ Med 2013;369:155-63.

28. Grijalva CG, Nuorti JP, Arbogast PG, et al. Decline in pneumonia admissions after routine childhood immunisation with pneumococcal conjugate vaccine in the USA: a time-series analysis. Lancet 2007;369:1179-86.

29. Koshy E, Murray J, Bottle A, et al. Impact of the seven-valent pneumococcal conjugate vaccination (PCV7) programme on childhood hospital admissions for bacterial pneumonia and empyema in England: national time-trends study, 1997-2008. Thorax 2010;65:770-4.

30. Patrzałek M, Albrecht P, Sobczynski M. Significant decline in pneumonia admission rate after the introduction of routine $2+1$ dose schedule heptavalent pneumococcal conjugate vaccine (PCV7) in children under 5 years of age in Kielce, Poland. Eur $\mathrm{J}$ Clin Microbiol Infect Dis 2010;29:787-92.

31. Benet T, et al. Microorganisms Associated With Pneumonia in Children. Clin Infect Dis 2017. 
32. Hammitt LL, Kazungu S, Morpeth SC, et al. A preliminary study of pneumonia etiology among hospitalized children in Kenya. Clin Infect Dis 2012;54(Suppl 2):S190-9.

33. Ruuskanen O, Lahti E, Jennings LC, et al. Viral pneumonia. Lancet 2011;377:1264-75.

34. Cardinale F, Cappiello AR, Mastrototaro MF, et al. Communityacquired pneumonia in children. Early Hum Dev 2013;89 Suppl 3:S49-S52.

35. Bosch AA, Biesbroek G, Trzcinski K, et al. Viral and bacterial interactions in the upper respiratory tract. PLoS Pathog 2013;9:e1003057.

36. Kash JC, Taubenberger JK. The role of viral, host, and secondary bacterial factors in influenza pathogenesis. Am J Pathol 2015;185:1528-36.

37. Jansen AG, Sanders EA, Van Der Ende A, et al. Invasive pneumococcal and meningococcal disease: association with influenza virus and respiratory syncytial virus activity? Epidemiol Infect 2008;136:1448-54.

38. Murdoch DR, Jennings LC. Association of respiratory virus activity and environmental factors with the incidence of invasive pneumococcal disease. J Infect 2009;58:37-46.

39. Madhi SA, Klugman KP; Vaccine Trialist Group. A role for Streptococcus pneumoniae in virus-associated pneumonia. Nat Med 2004;10:811-3.

40. Fathima P, Blyth CC, Lehmann D, et al. The impact of pneumococcal vaccination on bacterial and viral pneumonia in Western Australian children: record linkage cohort study of 469,589 births (1996-2012). Clin Infect Dis 2017.

41. Chappell KJ, et al. Respiratory Syncytial Virus Infection is Associated with Increased Bacterial Load in the Upper Respiratory Tract in Young Children. J Medical Microbiol Diagnosis 2013;S1:005.

42. Blyth CC, Webb SA, Kok J, et al. The impact of bacterial and viral co-infection in severe influenza. Influenza Other Respir Viruses 2013;7:168-76.

43. Kneyber MC, Blussé van Oud-Alblas $\mathrm{H}$, van Vliet $\mathrm{M}$, et al. Concurrent bacterial infection and prolonged mechanical ventilation in infants with respiratory syncytial virus lower respiratory tract disease. Intensive Care Med 2005;31:680-5.

44. Thorburn K, Harigopal S, Reddy V, et al. High incidence of pulmonary bacterial co-infection in children with severe respiratory syncytial virus (RSV) bronchiolitis. Thorax 2006;61:611-5.

45. Chorazy ML, Lebeck MG, McCarthy TA, et al. Polymicrobial acute respiratory infections in a hospital-based pediatric population. Pediatr Infect Dis J 2013;32:460-6.

46. DeVincenzo JP, EI Saleeby CM, Bush AJ. Respiratory syncytial virus load predicts disease severity in previously healthy infants. $J$ Infect Dis 2005;191:1861-8.

47. Vu HT, Yoshida LM, Suzuki M, et al. Association between nasopharyngeal load of Streptococcus pneumoniae, viral coinfection, and radiologically confirmed pneumonia in Vietnamese children. Pediatr Infect Dis J 2011;30:11-18.

48. Fuller JA, Njenga MK, Bigogo G, et al. Association of the CT values of real-time PCR of viral upper respiratory tract infection with clinical severity, Kenya. J Med Virol 2013;85:924-32.

49. Houben ML, Coenjaerts FE, Rossen JW, et al. Disease severity and viral load are correlated in infants with primary respiratory syncytial virus infection in the community. J Med Virol 2010;82:1266-71.

50. Moore HC, Jacoby P, Taylor A, et al. The interaction between respiratory viruses and pathogenic bacteria in the upper respiratory tract of asymptomatic Aboriginal and non-Aboriginal children. Pediatr Infect Dis J 2010;29:1-5.

51. Wiertsema SP, Chidlow GR, Kirkham LA, et al. High detection rates of nucleic acids of a wide range of respiratory viruses in the nasopharynx and the middle ear of children with a history of recurrent acute otitis media. J Med Virol 2011;83:2008-17.
52. Bogaert D, van Belkum A, Sluijter M, et al. Colonisation by Streptococcus pneumoniae and Staphylococcus aureus in healthy children. Lancet 2004;363:1871-2.

53. Hashida K, Shiomori T, Hohchi N, et al. Nasopharyngeal Streptococcus pneumoniae carriage in Japanese children attending day-care centers. Int J Pediatr Otorhinolaryngol 2011;75:664-9.

54. Sulikowska A, Grzesiowski P, Sadowy E, et al. Characteristics of Streptococcus pneumoniae, Haemophilus influenzae, and Moraxella catarrhalis isolated from the nasopharynges of asymptomatic children and molecular analysis of S. pneumoniae and $\mathrm{H}$. influenzae strain replacement in the nasopharynx. J Clin Microbiol 2004;42:3942-9.

55. Berkley JA, Munywoki P, Ngama M, et al. Viral etiology of severe pneumonia among Kenyan infants and children. JAMA 2010;303:2051-7.

56. Fry AM, Lu X, Chittaganpitch M, et al. Human bocavirus: a novel parvovirus epidemiologically associated with pneumonia requiring hospitalization in Thailand. J Infect Dis 2007;195:1038-45.

57. Mathisen M, Strand TA, Valentiner-Branth P, et al. Respiratory viruses in nepalese children with and without pneumonia: a case-control study. Pediatr Infect Dis J 2010;29:731-5.

58. World Health Organization (WHO). Manual for the laboratory identification and antimicrobial susceptibility testing of bacterial pathogens of public health importance in the developing world, 2003.

59. O'Brien KL, Bronsdon MA, Dagan R, et al. Evaluation of a medium (STGG) for transport and optimal recovery of Streptococcus pneumoniae from nasopharyngeal secretions collected during field studies. J Clin Microbiol 2001;39:1021-4.

60. Turner P, Po L, Turner C, et al. Detection of respiratory viruses by PCR assay of nasopharyngeal swabs stored in skim milk-tryptoneglucose-glycerol transport medium. J Clin Microbiol 2011;49:2311-3.

61. Hammitt LL, Murdoch DR, Scott JA, et al. Specimen collection for the diagnosis of pediatric pneumonia. Clin Infect Dis 2012;54(Suppl 2):S132-9.

62. Chidlow G, Harnett G, Williams S, et al. Duplex real-time reverse transcriptase PCR assays for rapid detection and identification of pandemic (H1N1) 2009 and seasonal influenza A/H1, A/H3, and $B$ viruses. J Clin Microbiol 2010;48:862-6.

63. Chidlow GR, Harnett GB, Shellam GR, et al. An economical tandem multiplex real-time PCR technique for the detection of a comprehensive range of respiratory pathogens. Viruses 2009;1:42-56.

64. Osterback R, Tevaluoto T, Ylinen T, et al. Simultaneous detection and differentiation of human rhino- and enteroviruses in clinical specimens by real-time PCR with locked nucleic Acid probes. $J$ Clin Microbiol 2013;51:3960-7.

65. Smith-Vaughan $\mathrm{H}$, Byun R, Nadkarni M, et al. Measuring nasal bacterial load and its association with otitis media. BMC Ear Nose Throat Disord 2006;6:10.

66. Greenland S, Drescher K. Maximum likelihood estimation of the attributable fraction from logistic models. Biometrics 1993;49:865-72.

67. Reed C, Madhi SA, Klugman KP, et al. Development of the Respiratory Index of Severity in Children (RISC) score among young children with respiratory infections in South Africa. PLoS One 2012;7:e27793.

68. WHO Multicentre Growth Reference Study Group. WHO child growth standards: length/height-for-age, weight-for-age, weight-forlength, weight-for-height and body mass index-for-age: Methods and development. 2006 http://www.who.int/childgrowth/standards/ technical_report/en/

69. Centers for Disease Control and Prevention. Clinical growth charts. 2000 https://www.cdc.gov/growthcharts/clinical_charts.htm (accessed 20 Oct 2017). 